\title{
Mineralogická charakteristika fosforitové konkrece s rodochrozitem z lokality Tabarky, severní Chřiby
}

\author{
Mineralogy of a rhodochrosite-bearing phosphorite concretion from the locality Tabarky, \\ northern part of the Chřiby Mts.
}

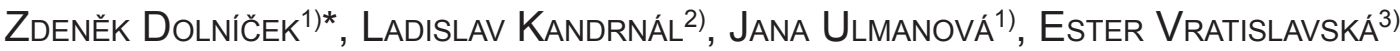 \\ a PaVel Hojač ${ }^{4)}$
}

${ }^{1) M i n e r a l o g i c k o-p e t r o l o g i c k e ́ ~ o d d e ̌ l e n i ́, ~ N a ́ r o d n i ́ ~ m u z e u m, ~ C i r k u s o v a ́ ~ 1740, ~} 19300$ Praha 9;

*e-mail: zdenek.dolnicek@nm.cz

${ }^{2)}$ Kameňák 145, 69650 Moravany u Kyjova

3) Vlastivědné muzeum, Palackého 70, 69701 Kyjov

4)Komenského 740, 69701 Kyjov

Dolniček Z, Kandrnál L, Ulmanová J, Vratislavská E, Hojač P (2020) Mineralogická charakteristika fosforitové konkrece s rodochrozitem z lokality Tabarky, severní Chřiby. Bull Mineral Petrolog 28(1): 35-43 ISSN 2570-7337

\begin{abstract}
The second occurrence of phosphorite in the Chriby Mts. was found in a secondary position (pebble from stream gravel) in the northern part of the mountain massif at the Tabarky site. Its original host rock environment were Cretaceous-to-Palaeocene flysch sediments of the Solán Formation, belonging to the Rača Unit of the flysch belt of the Outer Western Carpathians. Based on bulk chemical composition, the studied phosphorite concretion is formed by ca. $47 \mathrm{wt} \%$ of carbonate-fluorapatite, $31 \mathrm{wt}$ \% of carbonate (rhodochrosite to Fe-rich rhodochrosite), and $21 \mathrm{wt}$. \% of detritic admixture. The grains of carbonate are zoned with increasing Fe/Mn ratio from core to rim. Accessory pyrite with elevated contents $(0 . \mathrm{X}$ wt. \%) of $\mathrm{Mn}, \mathrm{Ni}, \mathrm{Co}, \mathrm{Cu}, \mathrm{As}$ and $\mathrm{Pb}$ as well as a very rare sphalerite were also found. Phosphorite is a product of early diagenetic processes operating in unconsolidated host deep-sea sediments. The material source of this mineralization was in unstable components of host sediments, which were remobilized by pore fluids under reducing conditions associated with shallow burial. The geochemical signature suggests that material resembling oceanic manganese nodules could have participated in the formation of the studied authigenic mineralization.
\end{abstract}

Key words: phosphorite, rhodochrosite, fluorapatite, chemical composition, Solán̆ Formation, Flysch belt, Western Carpathians, Chriby Mts.

Obdrženo 21. 1. 2020; prijiato 27. 3. 2020

\section{Úvod}

Fosfority představuji velmi vzácnou litologickou komponentu plošně rozsáhlých sedimentárních horninových komplexů české části flyšového pásma Západních Karpat. Vyskytují se v podobě drobných konkrecí o velikosti maximálně prvních centimetrů, které jsou uloženy v pískovcích nebo jílovcích křídového až paleogenního stáří. Dosud byly jejich výskyty v literatuře popsány ze slezské, podslezské a račanské jednotky. Ze svrchnokřídových sedimentů godulského souvrství slezské jednotky na profilu Bystrý potok u Trojanovic popsali nález až $4 \mathrm{~cm}$ velkých vejčitých fosforitových konkrecí černé barvy Matýsek, Skupien (2005). Matýsek, Bubík (2012) uvádějí z šedých paleogenních vápnitých jílů frýdeckého souvrství z lokality Zelinkovice (podslezská jednotka) výskyt světle hnědých hlízovitých fosforitových nodulí s hladkým povrchem o průměrné velikosti kolem $5 \mathrm{~cm}$. Nejnověji Dolníček et al. (2019) popsali nález oválné $5 \mathrm{~cm}$ velké fosforitové konkrece světle hnědé barvy $z$ rudní haldičky bývalého dolu na pelosiderit u Moravan (jižní Chřiby), situovaného $v$ křídových až paleogenních zelenošedých jílovcích ráztockých vrstev soláňského souvrství račanské jednot- ky. Matýsek, Bubík (2012) i Dolníček et al. (2019) dále uvádějí, že jsou jim v oblasti flyšového pásma Západních Karpat známy i další, zatím nepublikované výskyty konkrecionálních fosforitů.

Při terénní pochůzce se $v$ roce 2012 autorům předloženého pojednání podařilo nalézt fragment drobné konkrece na lokalitě Tabarky v severní části Chřibů, původně považované za pelosiderit. Provedená celohorninová chemická analýza tohoto vzorku ukázala, že jde o fosforit $\mathrm{s}$ príměsí karbonátů. Vzhledem $\mathrm{k}$ nečetnosti nálezů fosforitů $v$ oblasti karpatského flyše a jejich obecně malé moderní prozkoumanosti jsme nalezenému vzorku věnovali detailnější pozornost. Získané poznatky předkládáme $v$ tomto článku.

\section{Geologická pozice nálezu}

Popisovaná konkrece byla nalezena na severním okraji Chřibů v potoku Trňák, asi $1 \mathrm{~km}$ j. od jižního okraje Lubné a 1 km zjz. od Tabarek (obr. 1). Vzorek pochází z drobné štěrkové lavice, situované $v$ místě soutoku hlavního toku potoka a drobného pravostranného přítoku. Vzhledem k tomu, že se pramenné oblasti obou potoků 
nacházejí ve vzdálenosti maximálně 0.5 km od místa nálezu, je možná zdrojová oblast, z níž nalezený fosforit může pocházet, poměrně malá.

Geologicky se zájmová oblast nachází v horninách račanské jednotky magurského flyše (obr. 1). Podle geologické mapy 1 : 50000 jsou lokalita i celá snosová oblast nad lokalitou situovány $v$ ráztockých a lukovských vrstvách soláňského souvrství (obr. 1). Ráztocké vrstvy tvoři spodní oddíl soláňského souvrství a jde o křídové až paleogenní (maastricht až dan), drobně rytmické flyšové sedimenty s proměnlivým zastoupením jílovců a pískovců. Lukovské vrstvy, reprezentované převahou hrubě lavicovitých drobových a arkózových pískovců a slepenců, jsou paleocenního stárí (Buday et al. 1963; Stráník 1993; Chlupáč et al. 2002).

\section{Metodika}

Část studovaného vzorku byla použita pro celkovou chemickou analýzu, malý úlomek byl použit pro zhotovení nábrusu a zbytek vzorku zůstal zachován jako dokladový materiál. Vzorek pro celkovou chemickou analýzu o hmotnosti cca $5 \mathrm{~g}$ byl rozpráškován na analytickou jemnost ve vibračním mlýnku z chromniklové oceli (Katedra geologie PřF UP Olomouc). Homogenní práškový vzorek byl následně analyzován v laboratořích ACME (Vancouver, Kanada). Pro analýzu všech komponent vyjma těžkých kovů, ztráty žíháním, síry a uhlíku byl vzorek rozkládán tavením s $\mathrm{LiBO}_{2}$ a následným vyloužením ve zředěné $\mathrm{HNO}_{3}$. Zvláštní navážka pro analýzu těžkých kovů byla vyloužena lučavkou královskou za horka $\left(95^{\circ} \mathrm{C}\right)$. Hlavní oxidy, Ba a Sc byly stanoveny metodou ICP-OES, ostatní stopové prvky metodou ICP-MS. Uhlík, síra a ztráta žíháním byly stanoveny ze samostatné navážky na automatickém analyzátoru Leco. Obsahy prvků vzácných zemin (REE) byly normalizovány na C1 chondrit s využitím dat Anderse, Grevesseho (1989). Velikost Ce a Eu anomálie byla kvantifikována podle McLennana (1989).

Nábrus byl zhotoven zalitím úlomku fosforitu do epoxidové pryskyřice a naleštěním pomocí diamantových suspenzí. Dokumentace nábrusu $v$ odraženém světle byla provedena na odrazovém polarizačním mikroskopu Nikon Eclipse ME600. Následně byl preparát potažen uhlíkovým filmem o tloušt'ce $30 \mathrm{~nm}$ a studován na elektronové mikrosondě Cameca SX-100 v laboratoři Mineralogicko-petrologického oddělení Národního muzea $v$ Praze. Na prístroji byly pořízeny snímky ve zpětně odražených elektronech (BSE), provedena identifikace jednotlivých fází pomocí energiově disperzních (EDS) spekter a kvantitativně měřeno chemické složení vybraných fází ve vlnově disperzním (WDS) modu. Při bodových analýzách karbonátů a apatitu bylo použito urychlovací napětí 15 $\mathrm{kV}$, proud svazku $10 \mathrm{nA}$ a fokusovaný elektronový svazek o průměru cca $0.7 \mu \mathrm{m}$. Ve všech analýzách apatitu byly měřeny obsahy $\mathrm{Al}, \mathrm{As}, \mathrm{Ba}, \mathrm{Ca}, \mathrm{Ce}, \mathrm{Cl}, \mathrm{F}, \mathrm{Fe}, \mathrm{K}, \mathrm{Mg}$, $\mathrm{Mn}, \mathrm{Na}, \mathrm{P}, \mathrm{Pb}, \mathrm{S}, \mathrm{Si}, \mathrm{Sr}, \mathrm{Y}$ a $\mathrm{Zn}$, v karbonátech $\mathrm{Al}, \mathrm{Ca}$, $\mathrm{Co}, \mathrm{Cu}, \mathrm{Fe}, \mathrm{Mg}, \mathrm{Mn}, \mathrm{Na}, \mathrm{Ni}, \mathrm{P}, \mathrm{Pb}, \mathrm{S}, \mathrm{Si}, \mathrm{Sr}$ a $\mathrm{Zn}$. Použité analytické čáry a standardy: albit $(\mathrm{NaK \alpha})$, almandin (AlKa, FeKa), apatit (CaKa, PKa), baryt (BaL $\beta)$, celestin (SKa, SrL $\beta), \mathrm{CePO}_{4}(\mathrm{CeL} \alpha)$, Co (CoKa), diopsid (MgKa), halit $(\mathrm{ClK} \alpha)$, chalkopyrit (CuKa), klinoklas (AsL $\alpha)$, LiF $(\mathrm{FK \alpha}), \mathrm{Ni}(\mathrm{NiK \alpha})$, rodonit $(\mathrm{MnK \alpha})$, sanidin $(\mathrm{KK} \alpha)$, vanadinit (PbMa), wollastonit (CaKa, SiKa), $\mathrm{YVO}_{4}(\mathrm{YL \alpha})$ a zinkit (ZnKa). Při bodových analýzách sulfidů bylo použito urychlovací napětí $25 \mathrm{kV}$, proud svazku $20 \mathrm{nA}$ a průměr elektronového svazku $0.7 \mu \mathrm{m}$. Použité standardy a analytické čáry: $\mathrm{Ag}(\mathrm{AgL} \alpha), \mathrm{Au}(\mathrm{AuM \alpha}), \mathrm{Bi}_{2} \mathrm{Se}_{3}(\mathrm{BiM} \beta), \mathrm{CdTe}$ (CdLa), Co (CoKa), CuFeS 2 (CuKa, SKa), FeS 2 (FeKa), GaAs (GaL $\alpha)$, Ge (GeLa), HgTe (HgLa), InAs (InL $\alpha)$, $\mathrm{Mn}(\mathrm{MnK} \alpha), \mathrm{NaCl}(\mathrm{ClK} \alpha), \mathrm{NiAs}(\mathrm{AsL} \beta), \mathrm{Ni}(\mathrm{NiK \alpha}), \mathrm{PbS}$ (PbMa), PbSe (SeL $\beta$ ), PbTe (TeL $\alpha), \mathrm{Sb}_{2} \mathrm{~S}_{3}(\mathrm{SbL} \alpha), \mathrm{Sn}$ $(\mathrm{SnL \alpha})$ a $\mathrm{ZnS}(\mathrm{ZnK \alpha})$. Měrící časy na píku se pohybovaly mezi 10 a $30 \mathrm{~s}$, měřící časy pozadí trvaly polovinu času měření na píku. Načtená data byla přepočítána na hm. \% s použitím standardní PAP korekce (Pouchou, Pichoir 1985). Obsahy měřených prvků, které nejsou uvedeny v níže uvedených tabulkách, byly ve všech případech pod mezí stanovitelnosti.

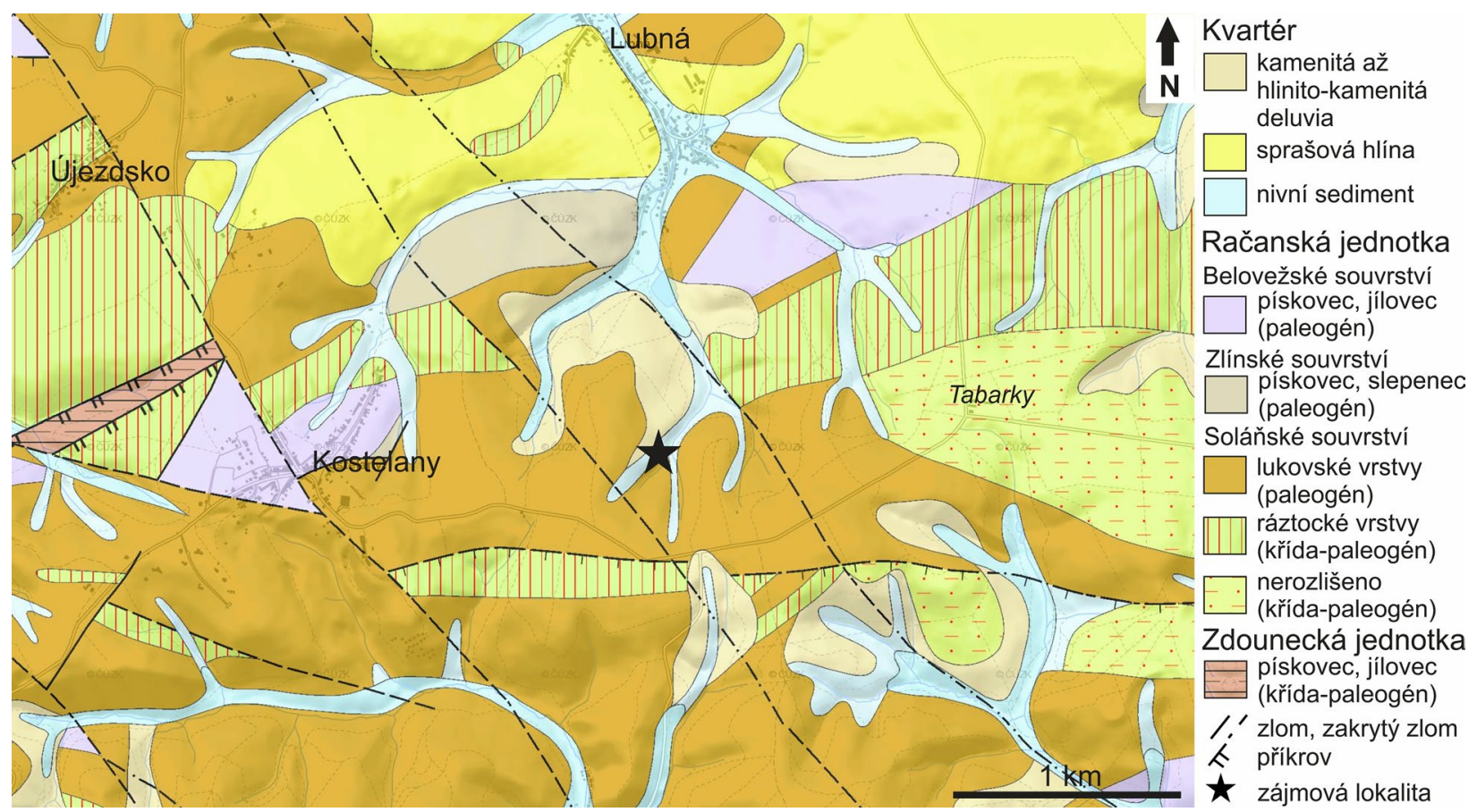

Obr. 1 Geologická pozice studované lokality. Podkladová mapa převzata a upravena z elektronické verze geologické mapy 1 : 50000 (www.geology.cz). 


\section{Charakteristika fosforitu}

Studovaný vzorek představuje úlomek oválné konkrece o rozměrech $4.5 \times 2 \mathrm{~cm}$. Povrch vzorku je pokryt tenkou černou mastně lesklou vrstvičkou (obr. 2a), tvořenou oxidy $\mathrm{Mn}$ (v kyselině chlorovodíkové vyvíjejí chlor). $\mathrm{Na}$ čerstvém řezu má hmota konkrece nahnědle šedou barvu, makroskopicky je celistvá, bez známek přednostního uspořádání či makroskopicky patrné zonálnosti. Septáriové trhliny nejsou prítomny. Působením 10\% kyseliny chlorovodíkové na úlomek konkrece nedochází za studena k žádné reakci, za varu nejprve dochází k reakci doprovázené vývojem bublinek $\mathrm{CO}_{2}$, který však po cca minutě ustává.

Podrobnější mineralogické studium zhotoveného nábrusu prokázalo př́tomnost tří základních složek apatitu, karbonátu (rodochrozitu) a klastické příměsi. Vedle nich byly $v$ akcesorickém množství nalezeny i pyrit a sfalerit. Klastická příměs odpovídá velikostí zrna pelitické až aleuritické frakci (obr. 2b - c). Mineralogicky je tvořena zejména angulárním až subangulárním křemenem, dále šupinami muskovitu, chloritu, jílovými minerály (podle EDS spekter patrně illit), akcesoricky byl zjištěn i K-živec, albit, zirkon a oxidy Fe. Klastická prríměs je uzavírána bud' prímo v zrnech, respektive agregátech karbonátu a apatitu, nebo se koncentruje $v$ intergranulárách mezi zrny a agregáty obou výše zmíněných autigenních fází (obr. 2c). I v prípadě intergranulár Ize však konstatovat prítomnost významného množství apatitového tmelu, jímž jsou částice klastické př́měsi pojeny (obr. 2c). Přítomnost mikrofosilií nebyla zjištěna.

Apatit je dominantní autigenní minerální fází. Je př́itomen ve dvou morfologických formách. Jednak vytvárí větší agregáty okrouhlého tvaru, dosahující velikosti 10 $50 \mu \mathrm{m}$, které se vyznačují oproti svému okolí zřetelně nižší porozitou. Jednotlivá zrna apatitu nelze $v$ agregátech na BSE snímcích rozlišit. Někdy tyto apatitové agregáty obsahují uzavřeniny větších zrn klastické príměsi nebo i rodochrozitu (obr. 2c), jindy se zdají být monominerální. $\checkmark$ některých případech agregáty tohoto typu naopak vyplňují prostor mezi hustě nahloučenými zrny rodochrozitu (obr. 2b). Druhou formou výskytu apatitu je jemný apatitový tmel, pojící jemnozrnnou klastickou príměs v intergranulárách mezi většími agregáty autigenních fází. Tento tmel je zřetelně více porézní a hojně prostoupený klastickými částicemi. V elektronovém mikroskopu je apatitová hmota kompozičně uniformní, bez patrné zonálnosti (obr. 2c). V homogenních apatitových agregátech je místy pa-

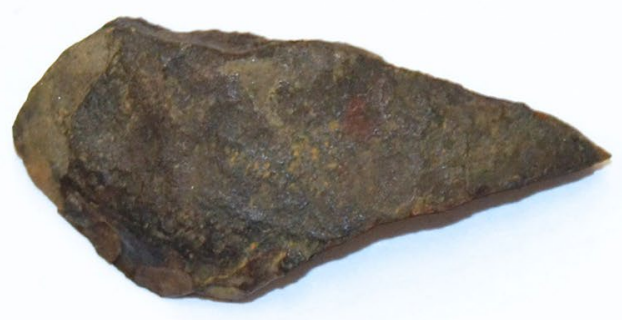

a

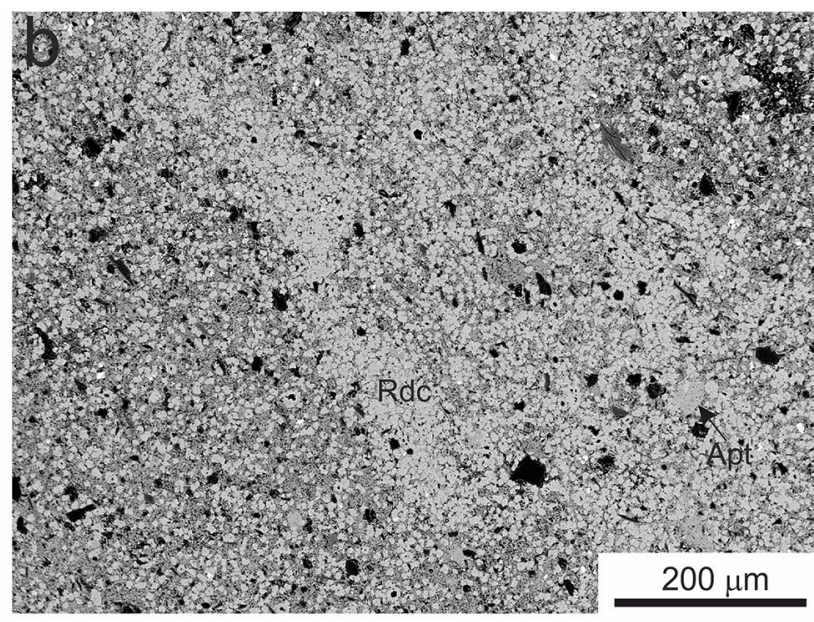

$2 \mathrm{~cm}$
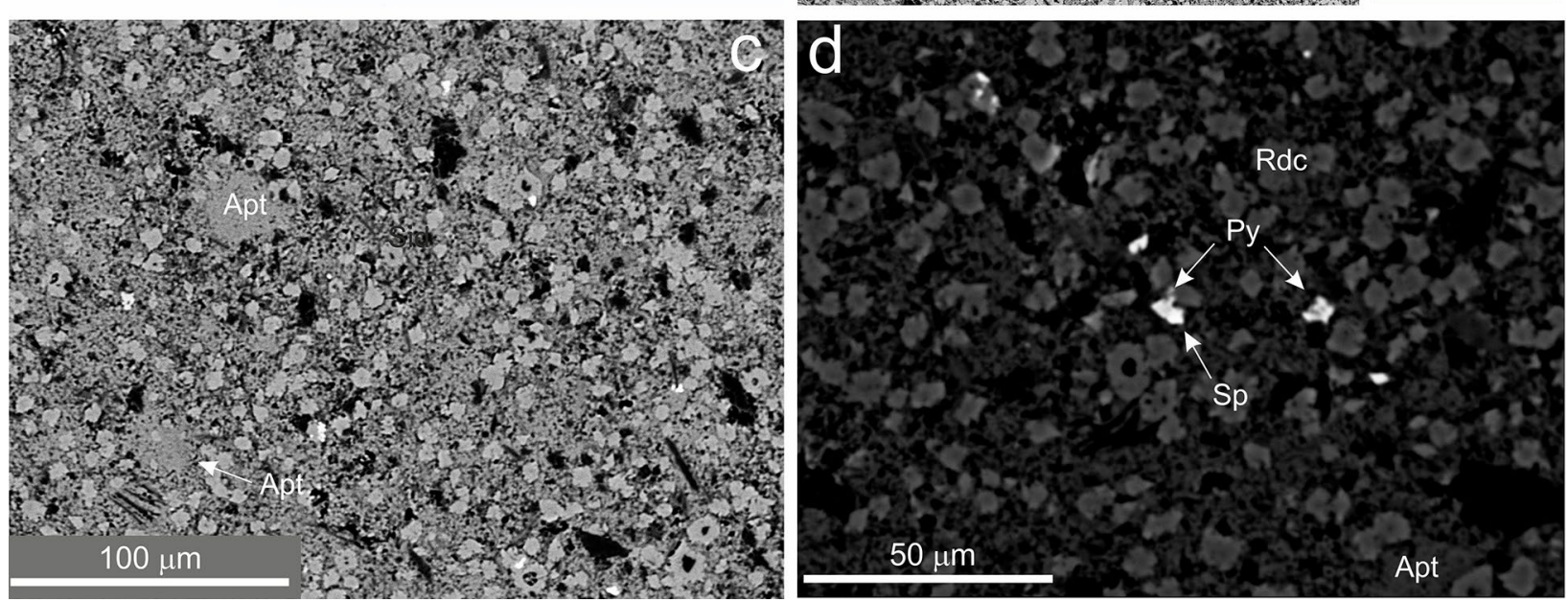

Obr. 2 Vzhled a minerální asociace studovaného vzorku fosforitu z Tabarek. a - makroskopický vzhled povrchu studovaného vzorku s černou krustou oxidů Mn. b - světlejší smouha tvořená hustě nahloučenými krystaly rodochrozitu (Rdc). V mezerní hmotě se mísí apatit (Apt) s jemnozrnnou siliciklastickou složkou. Černá jsou zrna detritické příměsi. Nábrus, obraz BSE. c - dva větší homogennější oválné agregáty apatitu (Apt), uzavírané spolu se světlejšími krystaly rodochrozitu v jemnozrnné matrici tvorené jemnou detritickou komponentou a porézním apatitovým tmelem. Bílá zrna patři pyritu. Obraz BSE. $d$ - izolované zrno sfaleritu (Sp), zčásti obrůstané pyritem (Py), uzavřené $v$ rodochrozit-apatitové matrici, BSE obraz. Makrofoto J. Ulmanová, BSE snímky Z. Dolníček. 
trný jemně porézní charakter apatitové hmoty, přičemž drobné póry okrouhlého tvaru neobsahují žádnou druhotnou minerální výplň.

Chemické složení apatitu bylo studováno pomocí 15 bodových WDS analýz (tab. 1). Chemismus je velmi homogenní bez ohledu na pozici analyzovaného místa v rámci konkrece. S ohledem na výraznou nestechiometrii většiny získaných analýz byly koeficienty empirického vzorce přepočítány na základ pěti atomů kovů $\vee$ pozici vápníku (tab. 1; srov. Kropáč et al. 2017). Vápník je v malé míře substituován zejména železem $(0.4-1.0 \mathrm{hm}$. \% FeO; 0.03 - 0.07 apfu Fe), méně i manganem (0.2 -

Tabulka 1 Př́klady chemického složení apatitu ze studovaného fosforitu. Obsahy oxidů v hm. \%, hodnoty apfu jsou vypočitány na základ pěti atomů kovů v pozici Ca. * - obsah $\mathrm{CO}_{2}$ dopočten na bázi $P+S+S i+C=3$ apfu.

\begin{tabular}{|c|c|c|c|c|c|c|c|c|c|c|c|c|c|c|}
\hline An. č. & 1 & 2 & 3 & 4 & 5 & 6 & 7 & 8 & 9 & 10 & 11 & 12 & 13 & 14 \\
\hline $\mathrm{SO}_{3}$ & 0.15 & 0.21 & 0.22 & .09 & 0.16 & 0.17 & 0.13 & 0.20 & 0.12 & 0.24 & 0.19 & 0.24 & 0.26 & 0.12 \\
\hline $\mathrm{P}_{2} \mathrm{O}_{5}$ & 38.65 & 38.54 & 38.96 & 37.35 & 38.92 & 37.97 & 36.16 & 36.13 & 36.28 & 38.43 & 38.83 & 39.12 & 38.52 & 35.91 \\
\hline $\mathrm{SiO}_{2}$ & 0.30 & 0.98 & 0.87 & 0.82 & 1.46 & 0.97 & 1.30 & 2.19 & 1.15 & 1.39 & 0.55 & 0.91 & 0.82 & 0.21 \\
\hline $\mathrm{CO}_{2}^{2}{ }^{*}$ & 2.17 & 1.07 & 1.13 & 2.83 & 0.47 & 1.67 & 1.53 & 0.32 & 2.21 & 0.84 & 0.64 & 0.77 & 1.05 & 2.39 \\
\hline $\mathrm{Al}_{2} \mathrm{O}_{3}$ & 0.63 & 0.79 & 0.69 & 0.51 & 0.66 & 1.27 & 1.46 & 0.63 & 0.83 & 0.59 & 0.38 & 0.60 & 0.59 & 0.15 \\
\hline $\mathrm{Ce}_{2} \mathrm{O}_{3}$ & 0 & 0.27 & 0.13 & 0.23 & 0 & 0.34 & 0.26 & 0.18 & 0.21 & 0.19 & 0.15 & 0.12 & 0 & 0 \\
\hline $\mathrm{CaO}$ & 53.96 & 52.83 & 53.35 & 52.41 & 52.83 & 52.64 & 49.66 & 50.02 & 52.28 & 52.33 & 52.59 & 53.33 & 53.09 & 9.43 \\
\hline $\mathrm{SrO}$ & 0 & 0 & 14 & .13 & 0 & .19 & 0 & 0.11 & 0.14 & 0.10 & 0 & 0 & 0.15 & 0 \\
\hline $\mathrm{MnO}$ & 0.44 & 0.48 & 0.46 & 0.60 & 0.44 & 0.43 & 0.44 & 0.47 & 0.39 & 0.27 & 0.22 & 0.27 & 0.33 & 0.34 \\
\hline $\mathrm{FeO}$ & 0.63 & 0.61 & 63 & 0.55 & 0.58 & 66 & 0.97 & 0.65 & 0.80 & 0.74 & 0.36 & 0.61 & .41 & 0.44 \\
\hline $\mathrm{Na}_{2} \mathrm{O}$ & 0.14 & 0 & 0 & .32 & 0.12 & 0 & 0.12 & 0 & 0 & 0.43 & 0 & 0 & 0 & 1.40 \\
\hline $\mathrm{K}_{2} \mathrm{O}$ & 0.34 & 0.13 & 0.20 & 0.15 & 0.11 & 0.12 & 0.31 & 0.16 & 0.11 & 0.15 & 0.05 & 0.12 & 0.11 & 0.08 \\
\hline ᄃ & 4.22 & 3.95 & 4.44 & 35 & 4.23 & 97 & 3.74 & 3.76 & 3.60 & 3.90 & 4.08 & 4.15 & 4.37 & 3.68 \\
\hline $\mathrm{O}=\mathrm{F}$ & -1.78 & -1.66 & 1.87 & -1.41 & -1.78 & -1.67 & -1.57 & 1.58 & -1.52 & -1.64 & 1.72 & -1.75 & -1.84 & -1.55 \\
\hline Celkem & 99.85 & 98.20 & 9.35 & 98.93 & 98.20 & 8.73 & 94.51 & 93.24 & 96.60 & 97.96 & 96.32 & 98.49 & 97.86 & 92.60 \\
\hline $\mathrm{S}^{6+}$ & 009 & 013 & 014 & 006 & .010 & 11 & .009 & 013 & 0.008 & 015 & .012 & .015 & 017 & 0.008 \\
\hline $5+$ & 2.720 & 2.779 & 2.782 & 608 & 811 & 15 & .693 & 750 & 2.635 & 2.768 & .864 & .817 & .791 & 2.685 \\
\hline $\mathrm{Si}^{4+}$ & 0.025 & .083 & 0.073 & 68 & 25 & 82 & 0.114 & 197 & 0.099 & 18 & .048 & .077 & 70 & .019 \\
\hline $\mathrm{C}^{4+}$ & 246 & 0.124 & 0.130 & 0.319 & 0.055 & 93 & 0.184 & 39 & 0.259 & 098 & 0.076 & .089 & .123 & 0.288 \\
\hline Ansi & 3.000 & 3.000 & 3.000 & 2.999 & 3.000 & 00 & 3.000 & 3.000 & 3.000 & 3.000 & 3.000 & 2.999 & 3.000 & 3.000 \\
\hline $\mathrm{Al}^{3+}$ & 062 & 079 & 069 & 50 & 066 & 26 & 151 & 67 & 0.084 & 059 & 039 & .060 & .060 & .016 \\
\hline $\mathrm{Ce}^{3+}$ & 0 & 0.008 & 0.004 & 0.007 & 0 & 0.011 & 0.008 & 0.006 & 0.007 & 0.006 & 0.005 & 0.004 & 0 & 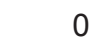 \\
\hline $\mathrm{Ca}^{2+}$ & 4.805 & 820 & 4.822 & 4.631 & 1.829 & 4.763 & 681 & 4.819 & 4.805 & 4.771 & 908 & 860 & 868 & 678 \\
\hline $\mathrm{Sr}^{2+}$ & 0 & 0 & 0.007 & 0.006 & 0 & 0.009 & 0 & 0.006 & 0.007 & 0.005 & 0 & 0 & 0.007 & 0 \\
\hline $\mathrm{Mn}^{2+}$ & & 35 & 0.033 & 42 & & 31 & & 0.036 & 0.028 & 0.019 & 16 & 19 & 0.024 & .025 \\
\hline $\mathrm{Fe}^{2+}$ & 0.044 & 0.043 & 0.044 & 0.038 & 0.041 & 47 & 0.071 & 0.049 & 0.057 & 0.053 & 26 & 43 & 029 & 0.032 \\
\hline $\mathrm{Na}^{+}$ & 0.023 & 0 & 0 & 0.211 & 0.020 & 0 & 0.020 & 0 & 0 & 0.071 & 0 & 0 & 0 & 0.240 \\
\hline $\mathrm{K}^{+}$ & 0.036 & .014 & .022 & 0.016 & 0.012 & 0.013 & 0.035 & 0.018 & 0.012 & 0.016 & 0.006 & 0.013 & 0.012 & 0.009 \\
\hline Cats & 5.000 & 5.000 & 5.000 & 5.000 & 5.000 & 5.000 & 5.000 & 5.000 & 5.000 & 5.000 & 5.000 & 5.000 & 5.000 & 5.000 \\
\hline $\mathrm{F}$ & 109 & 064 & 184 & 0.874 & 1.141 & 1.060 & 1.041 & 1.069 & 0.977 & 1.049 & 1.124 & 1.116 & 1.183 & 1.028 \\
\hline
\end{tabular}

Tabulka 2 Př́klady chemického složení karbonátů ze studovaného fosforitu. Obsahy oxidů v hm. \%, hodnoty apfu jsou vypočitány na základ jednoho atomu kovu.

\begin{tabular}{|c|c|c|c|c|c|c|c|c|c|c|c|c|c|c|}
\hline An. č. & 1 & 2 & 3 & 4 & 5 & 6 & 7 & 8 & 9 & 10 & 11 & 12 & 13 & 14 \\
\hline $\mathrm{SO}_{3}$ & 0 & c & 05 & 0 & 15 & 0 & & .05 & .07 & 0 & 0.07 & 0.13 & 0. & 0 \\
\hline $\mathrm{P}_{2} \mathrm{O}_{5}$ & 0.19 & 0 & 15 & 13 & 1.75 & 0.38 & 0 & 0 & 0 & 1.78 & 0.40 & 1.62 & 0.51 & 0 \\
\hline $\mathrm{SiO}_{2}$ & 0.37 & 0 & 0 & 0.68 & 1.68 & 0.56 & 1.50 & 1.12 & 0 & 1.20 & 0.85 & 2.35 & 2.46 & 1.65 \\
\hline $\mathrm{I}_{2} \mathrm{O}_{3}$ & 0.26 & 62 & 0.25 & 0.40 & 0.80 & 0.44 & 0.97 & 0.67 & 0.26 & 0.55 & 0.50 & 1.37 & 1.61 & 0.82 \\
\hline $\mathrm{gO}$ & & & 4 & & & & & & 91 & & & .46 & 97 & 57 \\
\hline $\mathrm{aO}$ & & & 7.37 & & 03 & 2 & 4 & 3.91 & 6.68 & .20 & 5.23 & 7.43 & 5.77 & 5.94 \\
\hline hO & & & 00 & & & & & 7 & & & & 30 & 2 & \\
\hline $\mathrm{eO}$ & 28 & & 36 & 88 & 80 & 45 & 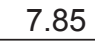 & .96 & 15 & & 55 & 5.04 & 3.69 & 9.90 \\
\hline Celk & 97 & 70 & .92 & 38 & 29 & 23 & 74 & 0.80 & .37 & 01 & 90 & 8.20 & 0.08 & 7.29 \\
\hline & 0 & 0 & & 0 & & 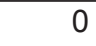 & 0 & 001 & .001 & 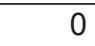 & & 02 & & \\
\hline $\mathrm{s}^{+}$ & & 0 & 03 & & 34 & & 0 & 0 & 0 & & 07 & 29 & 09 & \\
\hline $\lg ^{2+}$ & & & & & & & & & & & & & & 107 \\
\hline$a^{2+}$ & & & & & & & & & & & & & 24 & 128 \\
\hline$n^{2+}$ & & & & & & & & & & & & & & \\
\hline $\mathrm{e}^{2+}$ & 38 & 14 & 022 & & 0.054 & 74 & 36 & 0.171 & 0.170 & 34 & 0.286 & 0.263 & 0.313 & 0.334 \\
\hline atsum & 1.000 & .000 & .000 & 00 & 1.000 & 00 & .000 & .000 & 000 & 1.000 & 1.000 & 1.000 & .000 & 1.000 \\
\hline
\end{tabular}


0.6 hm. \% MnO; 0.01 - 0.04 apfu Mn) a draslíkem $\left(0.1-0.3 \mathrm{hm}\right.$. \% $\mathrm{K}_{2} \mathrm{O}$; $0.01-0.04$ apfu K), v polovině analýz i sodíkem $\left(0.0-1.4 \mathrm{hm}\right.$. \% $\mathrm{Na}_{2} \mathrm{O}$; $0.00-0.24$ apfu $\mathrm{Na})$ a stronciem (0.0 - 0.2 hm. \% SrO; 0.0 - 0.01 apfu Sr); nejasná je pozice průběžně zvýšeného obsahu hliníku $(0.2-1.5 \mathrm{hm}$. $\% \mathrm{Al}_{2} \mathrm{O}_{3} ; 0.02$ - 0.15 apfu $\mathrm{Al}$ ), která může pocházet i ze submikroskopických inkluzí jílových minerálů. Fosfor je $v$ malé míře zastupován sírou (0.1 - 0.2 hm. \% SO ; 0.01 apfu S) a snad i křemíkem (0.2 - 2.2 hm. \% $\mathrm{SiO}_{2} ; 0.01-0.20$ apfu Si), který však může být vázán i v inkluzích křemene či (spolu s Al) jílových minerálů. Obsahy prvků $v$ pozici fosforu jsou ve všech provedených analýzách deficitní, což by nasvědčovalo prítomnosti zvýšených obsahů $\mathrm{CO}_{2}$. Modelový dopočet na bázi $\mathrm{P}+\mathrm{S}+\mathrm{Si}+\mathrm{C}=3$ apfu nasvědčuje prítomnosti $0.3-2.8$ hm. \% $\mathrm{CO}_{2}$, odpovídající $0.04-0.32$ apfu C (tab. 1). Analýzy dále ukázaly 0.87 - 1.18 apfu $\mathrm{F}$; nadhodnocené obsahy nad 1 apfu mohou být zapříčiněny nevhodnou orientací analyzovaných zrn (Stormer et al. 1993). Obsahy $\mathrm{Cl}$ jsou ve všech analýzách pod limitem stanovitelnosti. Studovaný apatit tedy můžeme na základě jeho chemického složení označit jako karbonátovým anionem bohatý fluorapatit. Nízké analytické sumy většiny získaných analýz (92 - 97 hm. $\%$ po odpočtu ekvivalentu kyslíku za fluor a dopočtu $\mathrm{CO}_{2}$; tab. 1) pravděpodobně souvisejí s jemně porézním charakterem studované fáze.

Rodochrozit je druhou nejvýznamnější autigenní složkou studovaného fosforitu. Izometrická, xenomorfně až hypautomorfně omezená, postejně velká zrna rodochrozitu jsou obvykle jednotlivě vtroušena ve fosforitové matrici (obr. 2b-d). Méně časté jsou masivnější shluky rodochrozitových zrn, v nichž jsou jednotlivá zrna karbonátu uspořádána výrazně hustěji, takže se často navzájem dotýkají. Tyto rodochrozitem bohatší domény maji tvar nepravidelných smouh (obr. 2b) a vyskytují se ve vzorku zcela nahodile. Velikost zrn rodochrozitu se nejčastěji pohybuje mezi 5 a $10 \mu \mathrm{m}$. Často uzavírají drobné inkluze klastických fází, nezřídka bývá $v$ jejich středu drobné zrnko křemene (obr. 2d). V BSE obraze je u většiny zrn patrná slabá difuzní zonálnost, přičemž jádra zrn se jeví poněkud tmavší a okraje světlejší (obr. $2 c, d)$. Objemově v zrnech karbonátu zřetelně převažuje starší, v BSE obraze tmavší hmota.
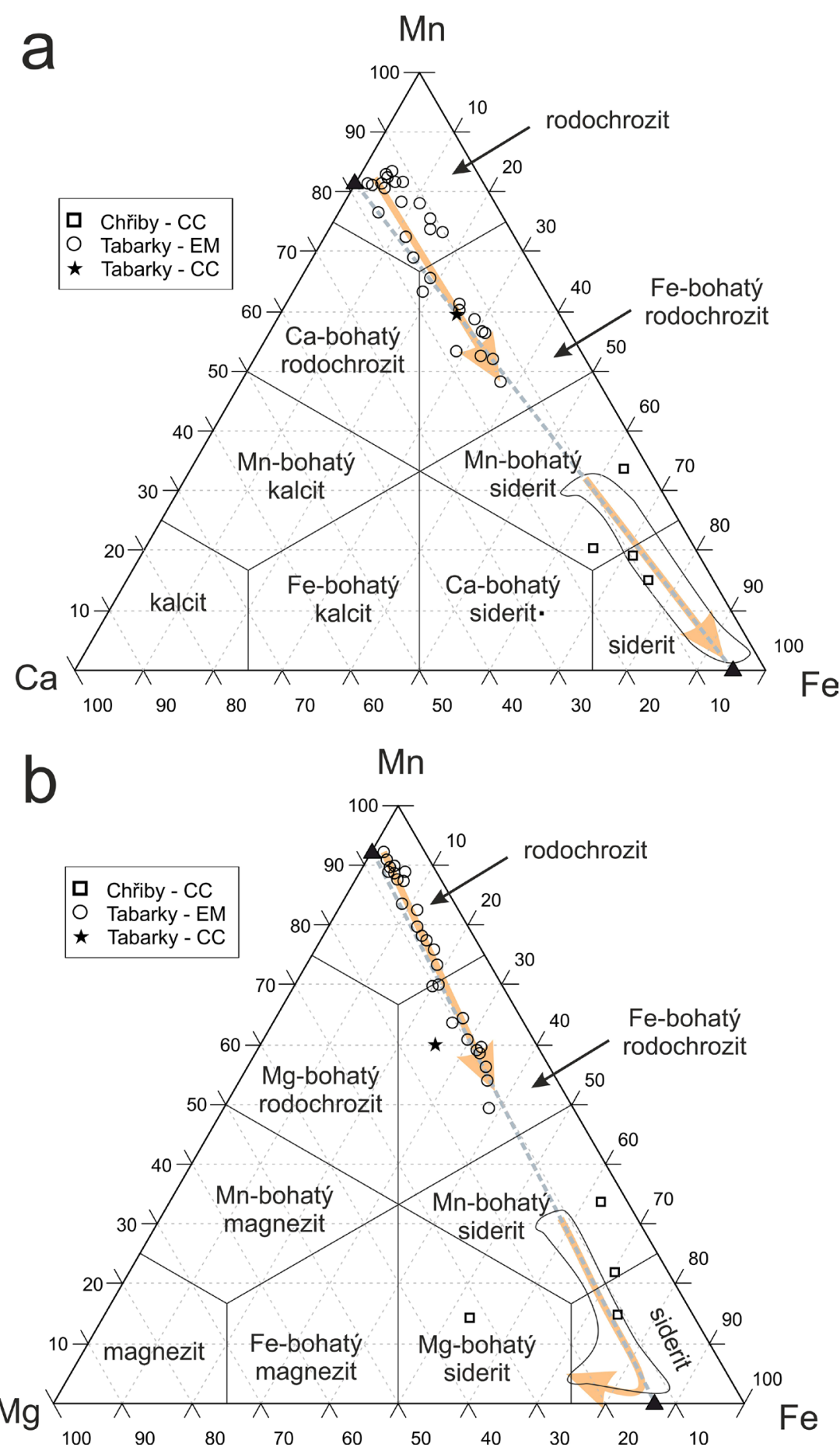

Obr. 3 Projekce chemického složení karbonátu z fosforitové konkrece z Tabarek v klasifikačních diagramech Trdličky a Hoffmana (1975). a - diagram Ca -Mn-Fe; b - diagram Mg-Mn-Fe. Vedle jednotlivých bodových mikrosondových analýz je vizualizováno i chemické složení „průměrného“ karbonátu, indikované z celkové chemické analýzy fosforitu (viz text). Pro porovnáni jsou vynesena i publikovaná data $k$ chemismu pelosideritú z oblasti Chřibů a Ždánického lesa (bodové značky; data ex Burkart 1953) a rozsah složení sideritu z pelosideritových konkrecí od Moravan (obrys datového pole; Dolníček et al. 2019). Šedé čárkované linie znázorňují lineární trendy definované distribucí dat z lokality Moravany, plnými trojúhelníčky je indikováno chemické složeni hypotetických krajních koncových členů z téže lokality (Dolníček et al. 2019). Oranžové šipky indikují vývoj chemismu karbonátů během krystalizace. EM - data z elektronové mikrosondy, CC - celková chemická analýza vzorku. 
Chemické složení rodochrozitu bylo studováno prostřednictvím 28 bodových WDS analýz. Reprezentativní výběr analýz je uveden v tabulce 2 a graficky jsou variace v chemismu ilustrovány na obrázku 3. Zvýšené obsahy Si a Al, zjištěné ve většině získaných analýz (tab. 2), Ize interpretovat ve smyslu anizominerálních submikroskopických inkluzí křemene a jílových minerálů, zarostlých v karbonátu. Zvýšený obsah fosforu Ize obdobně vysvětlit prítomností apatitu v analyzovaném „bodě“, prípadně může jít $v$ některých případech i o substituci fosforu za uhlík ve struktuře vlastního karbonátu ( $v$ případech, kdy nejsou zvýšené obsahy $\mathrm{P}$ doprovázeny zvýšenými obsahy $\mathrm{Ca}$ ). Chemické složení karbonátu je poměrně značně variabilní, zejména $v$ obsazích rodochrozitové (43.2 - 79.4 mol. \%) a sideritové (1.4 - 33.4 mol. \%) komponenty a méně i v obsazích kalcitové (8.6 - 17.2 mol. \%) a magnezitové (3.8 - 10.7 mol. \%) složky. Klasifikačně jde o rodochrozity až železem bohaté rodochrozity ve smyslu klasifikačního schématu Trdličky, Hoffmana (1975). Nejstarší tmavší ( $v$ obraze BSE) jádra karbonátových zrn mají nejvyšší obsahy Mn a odpovídají rodochrozitu. Světlejší (v obraze BSE) okrajové partie zrn mají výrazně nižší obsahy $\mathrm{Mn}$ a vyšší obsahy $\mathrm{Fe}$ a jde o železem bohaté rodochrozity (obr. 3). Většina dat vynesených v trojúhelníkových diagramech (obr. 3) definuje zřetelné lineární trendy. Jejich př́tomnost svědčí o tom, že zjištěnou variabilitu v chemismu můžeme interpretovat jako směsi dvou komponent $s$ vzájemně odlišným chemickým složením. $Z$ trendů je patrné, že s rostoucím obsahem Fe roste obsah $\mathrm{Mg}$, zatímco obsah $\mathrm{Ca} \vee$ karbonátu klesá (obr. 3). Zároveň existence lineárních trendů svědčí o neměnném zdroji matečných fluid a neměnnosti, případně pozvolném kontinuálním vývoji fyzikálně-chemických parametrů při krystalizaci (např. Eh, pH, teplota) během vzniku většiny karbonátové hmoty studovaných konkrecí.

Pyrit je akcesoricky prítomen $v$ podobě izolovaných vtroušených drobných zrn, které dosahují velikosti do $10 \mu \mathrm{m}$ (obr. 2c,d). Pyritová zrna jsou hypautomorfně až xenomorfně omezena a někdy bývají zčásti přeměněna v oxyhydroxidy Fe. V odrazovém mikroskopu je pyrit světle krémový, při zkřižených nikolech izotropní. Chemické složení bylo studováno pomocí devíti bodových WDS analýz (tab. 3). Chemické složení pyritu je poměrně komplexní, charakterizované zvýšenými obsahy řady dalších prvků, zejména olova $(0.17-1.58$ hm. \%; $0.001-0.009$ apfu $\mathrm{Pb})$, manganu (0.26 - $0.68 \mathrm{hm}$. \%; $0.006-0.015$ apfu Mn), niklu (0.03 - 0.50 hm. \%; $0.001-0.010$ apfu Ni), kobaltu (0.03 - 0.34 hm. \%; 0.001 - 0.007 apfu Co), mědi (0.15 - 0.44 hm. \%; $0.003-0.009$ apfu Cu) a s výjimkou jedné analýzy i arsenu (0.18 - 0.70 hm. \%; $0.003-0.012$ apfu As). Atomový poměr Co/Ni v získaných analýzách pyritů kolísá mezi 0.64 a 1.00 (tab. 3).

Sfalerit byl velmi vzácně zjištěn v podobě izolovaných vtroušených drobných zrn, které dosahují velikosti do 4 $\mu \mathrm{m}$ (obr. 2d). Zrna sfaleritu jsou xenomorfně omezena. Jedno zrno bylo obrůstáno mladším pyritem. Chemické složení bylo ověřeno pomocí dvou bodových WDS analýz (tab. 3). Vedle síry a zinku byly zjištěny i zvýšené obsahy železa (2.7 a 3.8 hm. \%), v menší míře i Cu, Pb a Mn (obsahy v rozmezí $0.3-0.5 \mathrm{hm}$. \%) a ještě méně In (kolem 0.1 hm. \%; tab. 3). Nelze vyloučit, že vzhledem k malým rozměrům sfaleritových zrn může část zvýšených obsahů Fe a Mn (tab. 3) pocházet z príměsi okolních karbonátů $v$ analyzovaném „bodě“.

Celková chemická analýza studované konkrece, již stručně prezentovaná v diplomové práci Křivánka (2015),

Tabulka 3 Chemické složení pyritu a sfaleritu ze studovaného fosforitu. Obsahy prvků v hm. \%, hodnoty apfu jsou vypočitány na základ dvou (pyrit), respektive jednoho (sfalerit) atomu síry.

\begin{tabular}{|c|c|c|c|c|c|c|c|c|c|c|c|}
\hline $\begin{array}{l}\text { An. č. } \\
\text { Minerál }\end{array}$ & $\begin{array}{r}1 \\
\text { pyrit }\end{array}$ & $\begin{array}{r}2 \\
\text { pyrit }\end{array}$ & $\begin{array}{r}3 \\
\text { pyrit }\end{array}$ & $\begin{array}{r}4 \\
\text { pyrit }\end{array}$ & $\begin{array}{r}5 \\
\text { pyrit }\end{array}$ & $\begin{array}{r}6 \\
\text { pyrit }\end{array}$ & $\begin{array}{r}7 \\
\text { pyrit }\end{array}$ & $\begin{array}{r}8 \\
\text { pyrit }\end{array}$ & $\begin{array}{r}9 \\
\text { pyrit }\end{array}$ & $\begin{array}{r}10 \\
\text { sfalerit }\end{array}$ & $\begin{array}{r}11 \\
\text { sfalerit }\end{array}$ \\
\hline $\mathrm{Fe}$ & 43.85 & 44.19 & 43.92 & 43.88 & 45.78 & 45.32 & 45.07 & 44.42 & 45.02 & 2.69 & 3.81 \\
\hline Co & 0.34 & 0.32 & 0.33 & 0.33 & 0.04 & 0.04 & 0.03 & 0.08 & 0.17 & 0 & 0 \\
\hline $\mathrm{Ni}$ & 0.46 & 0.50 & 0.47 & 0.49 & 0.04 & 0.05 & 0.03 & 0.09 & 0.20 & 0 & 0.03 \\
\hline $\mathrm{Cu}$ & 0.17 & 0.15 & 0.16 & 0.15 & 0.30 & 0.35 & 0.44 & 0.36 & 0.31 & 0.30 & 0.38 \\
\hline $\mathrm{Pb}$ & 1.58 & 1.49 & 1.54 & 1.43 & 0.17 & 0.21 & 0.32 & 0.27 & 0.26 & 0.38 & 0.35 \\
\hline $\mathrm{Zn}$ & 0 & 0 & 0 & 0 & 0 & 0 & 0 & 0 & 0 & 63.15 & 60.69 \\
\hline In & 0 & 0.05 & 0 & 0 & 0 & 0 & 0.06 & 0.08 & 0 & 0.08 & 0.11 \\
\hline $\mathrm{Mn}$ & 0.28 & 0.26 & 0.29 & 0.30 & 0.47 & 0.59 & 0.28 & 0.68 & 0.52 & 0.42 & 0.53 \\
\hline$S$ & 51.89 & 52.53 & 52.05 & 51.95 & 53.41 & 52.59 & 51.52 & 52.08 & 52.3 & 32.84 & 32.28 \\
\hline As & 0.21 & 0.18 & 0.21 & 0.20 & 0.39 & 0 & 0.70 & 0.30 & 0.45 & 0 & 0 \\
\hline Celkem & 98.78 & 99.67 & 98.97 & 98.73 & 100.58 & 99.14 & 98.45 & 98.36 & 99.23 & 99.85 & 98.18 \\
\hline $\mathrm{Fe}$ & 0.969 & 0.964 & 0.967 & 0.968 & 0.981 & 0.989 & 0.999 & 0.977 & 0.985 & 0.047 & 0.068 \\
\hline Co & 0.007 & 0.007 & 0.007 & 0.007 & 0.001 & 0.001 & 0.001 & 0.002 & 0.004 & 0 & 0 \\
\hline $\mathrm{Ni}$ & 0.010 & 0.010 & 0.010 & 0.010 & 0.001 & 0.001 & 0.001 & 0.002 & 0.004 & 0 & 0.001 \\
\hline $\mathrm{Cu}$ & 0.003 & 0.003 & 0.003 & 0.003 & 0.006 & 0.007 & 0.009 & 0.007 & 0.006 & 0.005 & 0.006 \\
\hline $\mathrm{Pb}$ & 0.009 & 0.009 & 0.009 & 0.009 & 0.001 & 0.001 & 0.002 & 0.002 & 0.002 & 0.002 & 0.002 \\
\hline $\mathrm{Zn}$ & 0 & 0 & 0 & 0 & 0 & 0 & 0 & 0 & 0 & 0.943 & 0.922 \\
\hline In & 0 & 0.001 & 0 & 0 & 0 & 0 & 0.001 & 0.001 & 0 & 0.001 & 0.001 \\
\hline $\mathrm{Mn}$ & 0.006 & 0.006 & 0.006 & 0.007 & 0.010 & 0.013 & 0.006 & 0.015 & 0.012 & 0.007 & 0.010 \\
\hline Catsum & 1.004 & 0.999 & 1.003 & 1.003 & 0.999 & 1.012 & 1.017 & 1.005 & 1.011 & 1.005 & 1.008 \\
\hline$S$ & 1.997 & 1.997 & 1.997 & 1.997 & 1.994 & 2.000 & 1.988 & 1.995 & 1.993 & 1.000 & 1.000 \\
\hline As & 0.003 & 0.003 & 0.003 & 0.003 & 0.006 & 0 & 0.012 & 0.005 & 0.007 & 0 & 0 \\
\hline Ansum & 2.000 & 2.000 & 2.000 & 2.000 & 2.000 & 2.000 & 2.000 & 2.000 & 2.000 & 1.000 & 1.000 \\
\hline $\mathrm{Co} / \mathrm{Ni}$ & 0.74 & 0.64 & 0.70 & 0.67 & 1.00 & 0.80 & 1.00 & 0.89 & 0.85 & & \\
\hline
\end{tabular}


je uvedena $v$ tabulce 4 . Dominantní jsou obsahy $\mathrm{CaO}$ $\mathrm{P}_{2} \mathrm{O}_{5}, \mathrm{SiO}_{2}, \mathrm{MnO}, \mathrm{FeO}$ a ztráty žíháním, které reflektují prítomnost výše zmíněných hlavních komponent - apatitu, karbonátu a klastické příměsi tvořené zejména křemenem a jílovými minerály. Pokud by $v$ daném vzorku nebyla přítomna žádná organická hmota, stanovený obsah uhlíku by odpovídal $12.39 \mathrm{hm}$. \% $\mathrm{CO}_{2}$. Orientační rozpočet chemické analýzy na jednotlivé hlavní složky nasvědčuje prítomnosti $47 \mathrm{hm}$. \% apatitu, $31 \mathrm{hm}$. \% karbonátu a 21 $\mathrm{hm}$. \% klastické příměsi. Prưměrné složení přítomného karbonátu vychází na 52.0 mol. \% rodochrozitu, 21.9 mol. $\%$ sideritu, 13.2 mol. \% kalcitu a 12.9 mol. \% magnezitu, a to za předpokladu odečtu ekvivalentního množství Ca vázaného v apatitu a snížení obsahu železa na hodnotu, která je (spolu s obsahy zbytku $\mathrm{CaO}$, všeho $\mathrm{MnO}$ a všeho $\mathrm{MgO}$ ) právě vázána výše uvedeným množstvím $\mathrm{CO}_{2}$. Chemismus tohoto „průměrného karbonátu“ je rovněž vizualizován $v$ grafech na obrázku $3, v$ nichž průmětné body $v$ obou diagramech padají do pole železem bohatého rodochrozitu. Zatímco v diagramu Fe-Mn-Ca (obr. 3a) takto získané složení velmi dobře reprezentuje možný průměr naměřených bodových mikrosondových analýz, v diagramu Fe-Mn-Mg (obr. 3b) je patrné výraznější obohacení o hořčík oproti bodovým mikroanalýzám. To signalizuje, že významná část hořčíku je vázána také v silikátech klastické príměsi ( $v$ chloritech, slídách, jílových minerálech). Vzhledem k nízkému celkovému obsahu Mg v daném vzorku (1.46 hm. \% MgO) však tato problematicky zakalkulovatelná nepřesnost významně neovlivní výše uvedený rozpočet chemické analýzy na jednotlivé základní složky. Na základě celkového chemického složení je tedy zřejmé, že $v$ dané konkreci převažuje apatit nad karbonátem a jde tedy z nomenklatorického hlediska o fosforit s príměsí rodochrozitu.

Ze stopových prvků (tab. 4) Ize zmínit zejména zvýšené podíly $\mathrm{Sr}$ (842 ppm), Ba (222 ppm) a REE (287 ppm), které mohou být vázány hlavně na apatit a méně na karbonát. Značně zvýšený obsah uranu (67 ppm) je pro sedimentární fosfority charakteristický. Zajímavé jsou také zvýšené obsahy přechodných kovových prvků (Zn - 76 ppm, Ni - 31 ppm, Co - 22 ppm, Cu - 7.5 ppm), vázané pravděpodobně hlavně v akcesorických sulfidech. Chondritem normalizovaná distribuce prvků vzácných zemin vykazuje obvyklý svrchnokorový vzor (pokles od La k Lu) se slabou pozitivní $\mathrm{Ce}$ anomálií $\left(\mathrm{Ce} / \mathrm{Ce}^{*}=1.28\right)$ a negativní Eu anomálií (Eu/Eu* = 0.71; obr. 4 a tab. 4).
Tabulka 4 Celkové chemické složení studovaného fosforitu. Obsahy oxidü, celkového uhlíku $\left(C^{\text {tot}}\right)$, celkové síry ( $\left.S^{\text {tot }}\right)$ a ztráty žiháním (LOI) v hm. \%, obsahy stopových prvků v ppm, vyjma zlata ( $v p p b)$.

\begin{tabular}{|c|c|c|c|}
\hline $\mathrm{P}_{2} \mathrm{O}_{5}$ & 20.03 & $\mathrm{Ag}$ & $<0.1$ \\
\hline $\mathrm{SiO}_{2}$ & 13.62 & As & 7.7 \\
\hline $\mathrm{TiO}_{2}$ & 0.17 & $\mathrm{Au}$ & 3.2 \\
\hline $\mathrm{Al}_{2} \mathrm{O}_{3}$ & 3.77 & $\mathrm{Ba}$ & 222 \\
\hline $\mathrm{Cr}_{2} \mathrm{O}_{3}$ & 0.01 & $\mathrm{Be}$ & $<1$ \\
\hline $\mathrm{FeO}^{\text {tot }}$ & 6.92 & $\mathrm{Bi}$ & 0.2 \\
\hline $\mathrm{MnO}$ & 10.36 & $\mathrm{Cd}$ & 0.2 \\
\hline $\mathrm{MgO}$ & 1.46 & Co & 22.1 \\
\hline $\mathrm{CaO}$ & 28.75 & Cs & 1.8 \\
\hline $\mathrm{Na}_{2} \mathrm{O}$ & 0.24 & $\mathrm{Cu}$ & 7.5 \\
\hline $\mathrm{K}_{2} \mathrm{O}$ & 0.64 & $\mathrm{Ga}$ & 23.5 \\
\hline LOI & 13.00 & $\mathrm{Hf}$ & 1.3 \\
\hline $\mathrm{C}^{\text {tot }}$ & 3.38 & $\mathrm{Hg}$ & 0.07 \\
\hline $\mathrm{S}^{\text {tot }}$ & 0.09 & Mo & 1.5 \\
\hline Celkem & 98.97 & $\mathrm{Nb}$ & 3.5 \\
\hline La & 60.6 & $\mathrm{Ni}$ & 31 \\
\hline $\mathrm{Ce}$ & 133 & $\mathrm{~Pb}$ & 13.2 \\
\hline $\mathrm{Pr}$ & 10.2 & $\mathrm{Rb}$ & 29.7 \\
\hline $\mathrm{Nd}$ & 39.6 & $\mathrm{Sb}$ & 0.2 \\
\hline $\mathrm{Sm}$ & 7.66 & Sc & 6 \\
\hline $\mathrm{Eu}$ & 2.09 & $\mathrm{Se}$ & $<0.5$ \\
\hline $\mathrm{Gd}$ & 10.5 & Sn & 2 \\
\hline $\mathrm{Tb}$ & 1.44 & $\mathrm{Sr}$ & 842 \\
\hline Dy & 8.94 & $\mathrm{Ta}$ & 0.3 \\
\hline Ho & 1.94 & Th & 3.6 \\
\hline $\mathrm{Er}$ & 5.54 & $\mathrm{TI}$ & $<0.1$ \\
\hline Tm & 0.67 & U & 66.6 \\
\hline $\mathrm{Yb}$ & 3.86 & V & 51 \\
\hline Lu & 0.62 & W & 0.9 \\
\hline$\sum$ REE & 287 & $Y$ & 97.6 \\
\hline $\mathrm{Ce} / \mathrm{Ce}^{*}$ & 1.28 & $\mathrm{Zn}$ & 76 \\
\hline $\mathrm{Eu} / \mathrm{Eu}^{*}$ & 0.71 & $\mathrm{Zr}$ & 74.5 \\
\hline
\end{tabular}

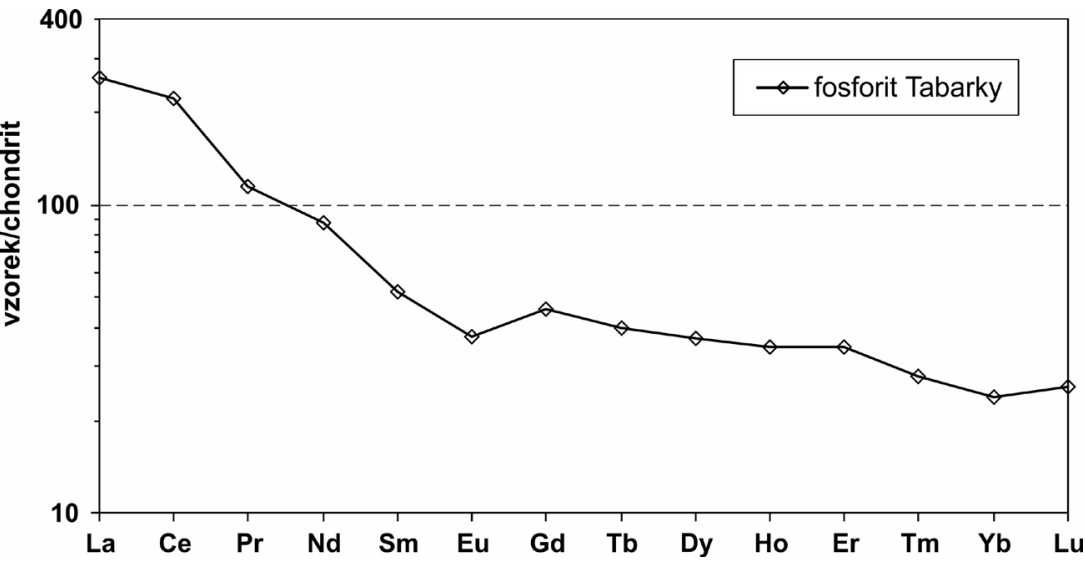

Obr. 4 Chondritem normalizovaná distribuce prvků vzácných zemin ve studovaném fosforitu.

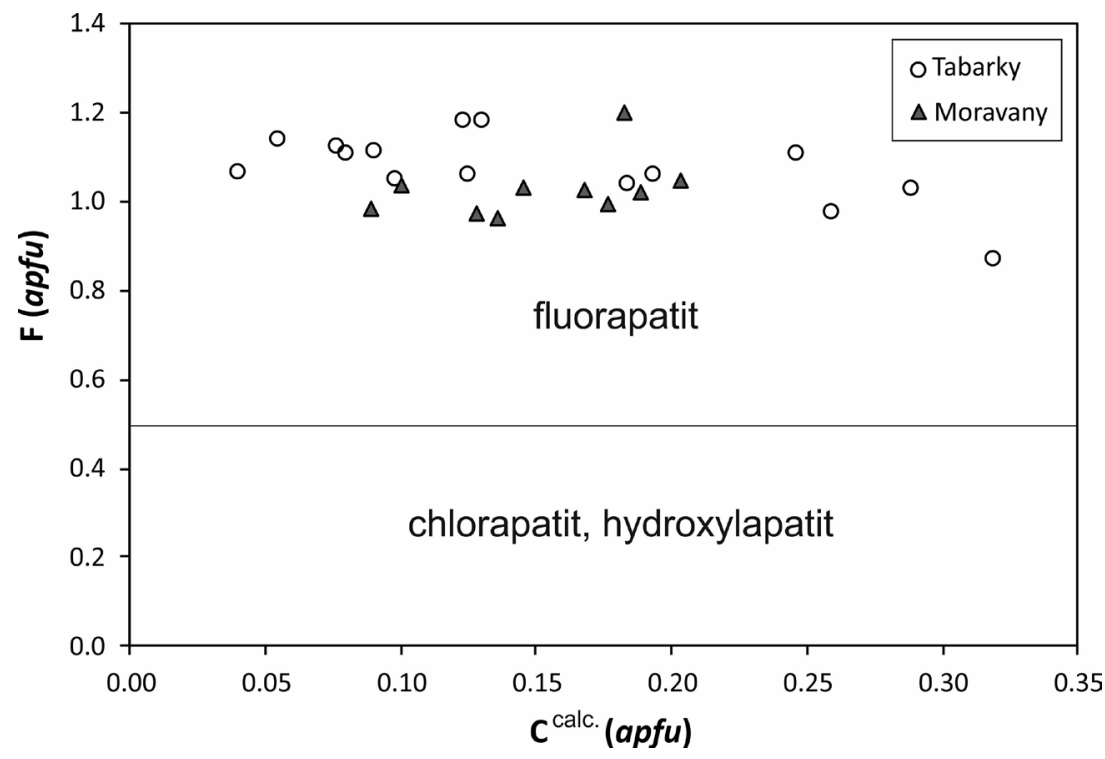

Obr. 5 Porovnání chemického složení karbonát-fluorapatitu z fosforitů z Chřibů. Data z Moravan převzata z Dolníčka et al. (2019). 


\section{Diskuse}

Popisovaný nález rozhojňuje dosavadní sporé údaje o výskytu fosforitů v oblasti flyšových sedimentů české části Vnějších Západních Karpat. Jde o již druhý nález $\checkmark$ prostředí sedimentů račanské jednotky v oblasti Chřibů. Třebaže byl studovaný fosforit nalezen v sekundární pozici, tj. jako klast $v$ potočním štěrku, z geologické situace je zřejmé, že jeho zdrojem musely být sedimenty soláňského souvrství, a to bud' vrstvy lukovské nebo vrstvy ráztocké (viz obr. 1). Z jílovců ráztockých vrstev z lokality Moravany v jižní části Chřibů pochází první nález fosforitu, zevrubně popsaný Dolníčkem et al. (2019). Na této lokalitě byla fosforitová konkrece nalezena $v$ asociaci s pelosideritovými konkrecemi. Při vzájemném srovnání obou výskytů Ize konstatovat pozoruhodně dobrou shodu v chemickém složení všech přitomných autigenních minerálních fází. Apatit v obou případech vykazuje obdobné minoritní obsahy $\mathrm{Sr}, \mathrm{S}, \mathrm{Al}$ a $\mathrm{Si}$, dále shodné obsahy $\mathrm{F}$ a také obdobný rozsah deficitu prvků v pozici fosforu, nasvědčující př́tomnosti obdobných obsahů $\mathrm{CO}_{2}$ ve strukturee apatitu (viz obr. 5). Pyrity mají na obou lokalitách zvýšené obsahy $\mathrm{Ni}, \mathrm{Co}, \mathrm{Pb}$ a Cu, k nimž v Moravanech navíc přistupuje někdy i Hg, zatímco na Tabarkách je charakteristicky prítomen As. Karbonáty se sice klasifikačně na obou lokalitách liší - pelosiderity v Moravanech jsou tvořeny Mn-bohatým sideritem až sideritem (ve fosforitu na dané lokalitě nebyl žádný karbonát zjištěn), zatímco karbonát z fosforitu z Tabarek patří rodochrozitu až Fe-bohatému rodochrozitu - nicméně většina dat $z$ obou lokalit definuje jednotný lineární trend, dobře patrný $v$ ternárních diagramech (obr. 3). Uvedené shodné rysy $v$ chemismu autigenních fází by tedy mohly naznačovat, že fosforit z Tabarek by také mohl pocházet z ráztockých vrstev; zde je však potřeba upozornit, že obdobně shodné geochemické charakteristiky nelze za současného stavu poznání vyloučit ani na lokalitách z jiných oblastí, respektive jiných tektonických jednotek karpatského flyše. Např́iklad Matýsek, Bubík (2012) rentgenometricky identifikovali ve fosforitu ze Zelinkovic (podslezská jednotka) př́tomnost karbonát-fluorapatitu (s cca $3.5 \mathrm{hm} . \% \mathrm{CO}_{2}$ ), pyritu, a také rodochrozitu. Stejně tak údaje v pracích Burkarta (1953) a Kropáče (2005) naznačují obdobný chemismus pelosideritových konkrecí z Hostýnských vrchů (račanská jednotka) i ze Ždánického lesa (ždánická jednotka) - viz obr. 3. Nelze tedy zcela vyloučit, že procesy vedoucí ke vzniku fosforitových a karbonátových konkrecí, probíhající na různých místech a $v$ různých časových obdobích, mohly vést ke vzniku konkrecí s obdobným chemickým složením autigenních minerálních fází. Podrobnější diskuse této problematiky zatím není možná vzhledem k minimálnímu množství dostupných moderních údajů o složení a chemismu konkrecí v karpatském flyši.

Vznik popisované fosforitové konkrece souvisel $s$ raně diagenetickými procesy $v$ hostitelských flyšových sedimentech. Texturní vztahy mezi apatitem a rodochrozitem naznačuji časově sblíženou krystalizaci obou autigenních fází. Pozorovaná zonálnost karbonátových zrn nasvědčuje poklesu obsahu $\mathrm{Mn}$ a nárůstu obsahu Fe během krystalizace. Zcela stejný vývojový trend popisují i Dolníček et al. (2019) z pelosideritových konkrecí na lokalitě Moravany. Tato pozorování jsou v dobré shodě s geochemickými poznatky z recentních mořských sedimentů, v nichž je nejprve do pórových vod $v$ sedimentu mobilizován mangan a až později železo (Froelich et al. 1979). $\mathrm{V}$ tomto pojetí mohou představovat konkrece z Tabarek (studované $v$ této práci) a $z$ Moravan (studované v práci Dolníčka et al. 2019) doklady rané (Mn > Fe; Tabarky) a pozdní (Fe > Mn; Moravany) fáze téhož minerogenetického procesu.

Zdrojem prvků pro tvorbu konkrecí jsou některé méně stabilní detritické či autigenní minerální fáze přítomné $\checkmark$ hostitelských sedimentech, jež za změněných podmínek (Eh, pH) po překrytí sedimentem přestávají být stabilní a rozpouštějí se $v$ pórových roztocích. $Z$ takto mineralizovaných pórových vod pak může docházet za vhodných podmínek $\mathrm{k}$ vylučování autigenních minerálních fází $v$ podobě konkrecí. Vzhledem $\mathrm{k}$ tomu, že k remobilizaci Fe a $\mathrm{Mn}$ a následnému vzniku autigenních $\mathrm{Fe}-\mathrm{Mn}$ karbonátů dochází ve vysloveně redukčním prostředí (v podmínkách „sulfátové“ či „metanogenní“ zóny; např. Gautier 1982; Fisher et al. 1997; Raiswell, Fisher 2000; Bąk 2007), patří $\mathrm{k}$ hlavním zdrojům zmíněných kovů oxidické minerály Fe a $\mathrm{Mn}$, které jsou $\mathrm{v}$ takovém prostředí málo stabilní. Dolníček et al. (2019) uvažují na základě geochemického charakteru (prvková asociace Mn-Fe-Ni-Co-Cu) autigenní mineralizace konkrecí z lokality Moravany i o uplatnění materiálu z oxidických oceánských manganových nodulí. $\checkmark$ prípadě fosforitu $z$ Tabarek Ize konstatovat prítomnost shodné prvkové asociace. Navíc př́tomnost pozitivní $\mathrm{Ce}$ anomálie ve fosforitu $z$ Tabarek nelze vysvětlit $v$ dané situaci jinak, nežli jako signaturu zděděnou ze zdroje (protolitu charakteru precipitátu), vzniklého v oblasti rozhraní anoxické a oxické mořské vody, což je prostředí charakteristické pro vznik oceánských oxidických manganových krust a nodulí (srov. Roy 1992). Zdrojem apatitu pro tvorbu fosforitu mohl být jednak detritický materiál hostitelských sedimentů, jednak „místní“ biotické zdroje (skelety a exkrementy mořských živočichů), nebot' prímou krystalizaci „primárního“ apatitu z mořské vody nelze v podmínkách hluboké mořské pánve očekávat (Knudsen, Gunter 2002). Vzhledem ke sblíženosti krystalizace rodochrozitu i apatitu předpokládáme, že remobilizace a následná sběrná krystalizace apatitu byla realizována během stejného procesu, při němž vznikly i karbonáty. Řadou badatelů je zdůrazňován dlouhodobý charakter procesu diagenetické krystalizace a zrání apatitu, kdy v první fázi vzniká nestabilní gel fosforečnanu vápenatého, který je během další interakce s pórovými vodami stabilizován přijetím fluoridových a karbonátových aniontů za vzniku karbonátfluorapatitu (Slansky 1986; Froelich et al. 1988; Stalder, Rozendaal 2004). Vzniku z původně gelové substance by mohl nasvědčovat jemně porézní charakter apatitu $v$ námi studovaném fosforitu.

\section{Závěr}

V práci je popsán druhý nález fosforitu z oblasti Chřibů, který byl uskutečněn $v$ sekundární pozici (klast $v$ potočním štěrku) v severní části horského masivu. Původním hostitelským horninovým prostředím fosforitu byly sedimenty soláňského souvrství (křída až paleogén) račanské jednotky magurského flyše. Podle provedené celkové chemické analýzy je fosforit tvořen cca $47 \mathrm{hm}$. $\%$ karbonát-fluorapatitu, $31 \mathrm{hm}$. \% karbonátu (rodochrozit až železem bohatý rodochrozit) a $21 \mathrm{hm}$. \% detritické příměsi. Zrna karbonátu jsou zonální, přičemž od středu k okraji roste poměr Fe/Mn. Akcesoricky je ve fosforitu přitomen i pyrit se zvýšenými obsahy $\mathrm{Mn}, \mathrm{Ni}, \mathrm{Co}, \mathrm{Cu}, \mathrm{As}$ a $\mathrm{Pb}$ (s obsahy řádově $0 . \mathrm{X} \mathrm{hm}$. \%); zcela ojediněle byl zaznamenán i výskyt sfaleritu. Fosforit představuje produkt raně diagenetických procesů $v$ nezpevněných hostitelských flyšových sedimentech. Látkový zdroj mineraliza- 
ce Ize spatřovat v nestabilních detritických i autigenních složkách hostitelských sedimentů, které byly remobilizovány pórovými vodami $v$ redukčních podmínkách během mělkého pohřbení. Geochemické rysy mineralizace naznačují, že se na vzniku fosforitu mohl podílet i materiál blízký oceánským manganovým nodulím.

\section{Poděkování}

Práce na dané problematice byly finančně podpořeny Ministerstvem kultury ČR v rámci institucionálního financování dlouhodobého koncepčního rozvoje výzkumné organizace Národní muzeum (DKRVO 2019-2023/1.II.b, 00023272).

\section{Literatura}

Anders E, Grevesse N (1989) Abundances of the elements: Meteoritic and solar. Geochim Cosmochim Acta 53: 197-214

BĄK K (2007) Organic-rich and manganese sedimentation during the Cenomanian-Turonian boundary event in the Outer Carpathian basins; a new record from the Skole Nappe, Poland. Palaeogeogr Palaeoclimatol Palaeoecol 256: 21-46

Buday T, Benešová E, BŘezina J, Cicha I, Čtyroký P, Dornič J, DVoŘÁK J, Eliáš M, Hanzlíková E, JendREJáková O, KaČura G, Kamenický J, Kheil J, Köhler E, Kullmanová A, Mahel' M, MatěJja A, Paulík J, Salaj J, Scheibner E, Scheibnerová E, Stehlík O, URbánek L, VavŘínová M, ZeLMAN J (1963) Vysvětlivky k přehledné geologické mapě ČSSR 1:200 000 M-33-XXX Gottwaldov. Ústř Úst geol Praha

BurkART E (1953) Mährens Minerale und ihre Literatur. Nakl Čs Akad věd, Praha

Dolniček Z, KandRnál L, Ulmanová J, VRatislavská E, Hojač P (2019) Historická těžba pelosideritů na lokalitě Koryčanská cesta u Moravan, jižní Chřiby. Bull Mineral Petrolog 27: 304-316

Fisher QJ, RaIswell R, Marshall JD (1997) Siderite concretions from nonmarine shales (Westphalian A) of the Pennines, England: controls on their growth and composition. J Sediment Res 68: 1034-1045

Froelich PN, Arthur ma, Burnett WC, Deakin M, Hensley V, Jahnke R, Kaul L, Kim K-H, Roe K, Soutar A, VATHAKANON C (1988) Early diagenesis of organic matter in Peru continental margin sediments: phosphorite precipitation. Mar Geol 80: 309-343

Froelich PN, Klinkhammer GP, Bender ML, LüdtKe NA, Heath GR, Cullen D, Dauphin P, Hammond D, Hartman B, MAYNARD V (1979) Early oxidation of organic matter in pelagic sediments of the eastern equatorial Atlantic: suboxic diagenesis. Geochim Cosmochim Acta 43: 1075-1090

GAUTIER DL (1982) Siderite concretions: indicators of early diagenesis in the Gammon Shale (Cretaceous). J Sediment Petrol 52: 859-871

Chlupáč I, Brzobohatý R, Kovanda J, Stráník Z (2002) Geologická minulost České republiky. Academia Praha
KNUdSEN AC, GUNTER ME (2002) Sedimentary phosphorites - an example: Phosphoria Formation, southeastern Idaho, U.S.A. Rev Mineral Geochem 48: 363389

KROPÁČ K (2005) Petroarcheologický výzkum stavebního kamene zříceniny hradu Obřany. MS, diplomová práce, PřF UP Olomouc

Kropáč K, DolničeK Z, Uher P, URUBek T (2017) Fluorcaphite from hydrothermally altered teschenite at Tichá, Outer Western Carpathians, Czech Republic: compositional variations and origin. Mineral Mag 81: 1485-1501

KŘIVÁNEK J (2015) Mineralogické studium artefaktů po železářské výrobě z vybraných lokalit $v$ okolí Starého Města u Uherského Hradiště. MS, diplomová práce, PřF UP Olomouc

MATÝSEK D, BuBík M (2012) Fosfát a pelokarbonát z pelitů podslezské jednotky na stavbě silnice R48 u Frýdku-Místku, Česká republika. Geol výzk Mor Slez 19: 88-91

MATÝSEK D, SKuPIEN P (2005) Fosforitové konkrece ve svrchní křídě slezské jednotky. Geol výzk Mor Slez $v$ roce 2004: 34-36

McLenNAN SM (1989) Rare earth elements in sedimentary rocks: influence of provenance and sedimentary processes. Rev Mineral 21: 169-200

Pouchou JL, PICHOIR F (1985) "PAP" ( $\varphi \rho Z)$ procedure for improved quantitative microanalysis. In: ARMSTRONG JT (ed.) Microbeam Analysis: 104-106. San Francisco Press, San Francisco

RAISWELL R, FISHER QJ (2000) Mudrock-hosted carbonate concretions: a review of growth mechanisms and their influence on chemical and isotopic composition. J Geol Soc London 157: 239-251

Roy S (1992) Environments and processes of manganese deposition. Econ Geol 87: 1218-1236

SLANSKY M (1986) Geology of sedimentary phosphates. North Oxford Academic, London

Stalder M, RozendaAl A (2004) Apatite nodules as an indicator of depositional environment and ore genesis for the Mesoproterozoic Broken Hill-type Gamsberg Zn$\mathrm{Pb}$ deposit, Namaqua Province, South Africa. Miner Deposita 39: 189-203

Stormer JCJR, PIeRson MJ, TACKer RC (1993) Variation of $\mathrm{F}$ and $\mathrm{Cl} \mathrm{X}$-ray intensity due to anisotropic diffusion of apatite during electron microprobe analysis. Am Mineral 78: 641-648

STRÁNík Z (1993) Flyšové pásmo Západních Karpat, autochtonní mesozoikum a paleogén na Moravě a ve Slezsku. In Pěıchystal A, Obstová V, Suk M (eds) Geologie Moravy a Slezska: 107-122. Prírodovědecká fakulta Masarykovy univerzity Brno

TRDLIČKA Z, HofFMAN V (1975) Untersuchungen der chemischen Zusammensetzung der Gangkarbonate von Kutná Hora (ČSSR). Freiberg Forschungshefte 6: 2981 